\title{
Critical Discourse Analysis In Netizen's Humor Comments Theme "Curhat Pilpres 2019" In Kumparan Online News
}

\author{
${ }^{1}$ Ika Febriani \\ ${ }^{1}$ \{ikafebriani@trunojoyo.ac.id $\}$ \\ ${ }^{1}$ Universitas Trunojoyo Madura, Madura, Indonesia
}

\begin{abstract}
In this study, humorous netizen comments on Twitter contained the presidential election reported by Kumparan online media were analyzed. The substance of netizen's perceptions regarding the third round of the 2019 presidential election debate. In the debate, Vice president candidate KH Ma'ruf Amin and Sandiaga Uno argued. The purpose of this study is to describe the text structure, practice of discourse, and sociocultural practices in netizen's perceptions of the debate through humor comments. Fairclough's theory reviews the commentary data as the manifestation of citizen perceptions. The results of textual analysis (micro-level) are shown in the use of vocabulary and grammar. The analysis of the practice of discourse (middle-level) describes the netizen's perceptions in humor comments as a medium for understanding life and as entertainment. The analysis of socio-cultural practices (macro-level) shows that netizen's perceptions based on social and cultural were dominated by romance.
\end{abstract}

Keywords: presidential election debate, critical discourse analysis, perception, netizen humor comments.

\section{INTRODUCTION}

Today, the rapid development of information technology has changed the culture of the world community. In this case, it includes the way humans socialize. This was demonstrated by the way humans interact and communicate through social media, which is increasingly easy and inexpensive in the era of the industrial revolution. Social media is the source of everything related to human life in the world. That is also the case in Indonesia. In the competition for the nomination of the presidential election in 2019, in general, the debates of presidential candidates are held by the general election organizing body, namely the KPU (General Election Commission).

Citizens in the social media they have are also not immune to the discussion and discussion of the presidential debate. This has become part of the culture of millennial society. One interesting thing in this research data is the humor delivered in the form of a comment on Twitter which is connected with the contents of the 2019 presidential election debate. It is an interactive discourse which, according to [1] is "something that produces something else - may be an idea concept, or effect - in communication events that take place through computer media and internet channels so that in the context of this study "interactive discourse" is seen as "interaction" and "power relations" between the media as producers of news texts and 
responders as producers of comments and between fellow responders. This invites humor because of the facts contained in the contents of the 2019 Presidential Election debate then becomes humor by means of certain language games between respondents so that it can entertain the reader.

The theory used in this study is Norman Fairclough's Critical Discourse Analysis theory. The theory states that there are three concepts in the analysis of critical discourse. These three concepts are the concept of the structure of the work, the concept of the practice of citizenship, and sociocultural practices. The concept of the structure of a literary work views a citizen's comments humor as a work in the form of a lingual structure.

\section{METHODOLOGY}

In this study, a qualitative approach with descriptive techniques was used to examine the humorous comments of citizens about the debates of the 2019 Indonesian presidential candidates. The research data consisted of ten humorous jokes from citizens about the third round of presidential debates held at the Sultan Hotel, Jakarta. Data was collected by documentation techniques on the device screenshot feature. This is considered effective for documenting news texts on the online media Kumparan.com which talks about the comments of Indonesian citizens based on observations when the presidential debates are played. Data Analysis Techniques were carried out in accordance with the data analysis techniques of Critical Discourse Analysis theory pioneered by Norman Fairclough, namely description, interpretation, and explanation[2]. The three steps of Fairclough's analysis according to[3] are carried out simultaneously in accordance with the basic assumptions of the relationship between micro structures (text) and macro structures (institutions and society).

Discourse analysis according to [4] is typically based on the language spoken by someone else, not the analyzer. This relates to the opinion of Fairclough follows. [5] said that CDA is an analysis of the dialectical relationships between semiosis (including language) and other elements of social practices. Furthermore according to Fairclough Its particular concern is with the radical changes that are taking place in contemporary social life, with how semiosis figures within the process of a change, and with shifts in the relationship between semiosis and other social elements within networks of practices. This is consistent with the opinion of [6] that critical discourse analysis conceptualizes language as a form of social practice. This means that critical discourse analysis also analyzes intent which, according to [7], is something that is outside of the speech.

\section{FINDINGS AND DISCUSSON}

The theory used in this study is Norman Fairclough's Critical Discourse Analysis theory. The theory states that there are three concepts in the analysis of critical discourse. These three concepts are the concept of the structure of the work, the concept of practice of citizenship, and sociocultural practices. The concept of structure of a literary work views a citizen's humorous commentary as a work in the form of a specific linguistic structure. The concept of the practice of discourse is how a text about the 2019 presidential election ventures as a practice of producing discourse and the practice of consuming discourse. The concept of socio-cultural practices is that language is seen as a socio-cultural practice supporting the holding of the 2019 presidential election debate. 
The interdisciplinary approach of CDA allows us to consider a wide variety of communicative methods and media from different perspectives in a way that does justice to the complexity linguistic, extralinguistic and contextual components of authentic, real-life communication[8]. This means that in the analysis of critical discourse language is seen as a complex power practice that affects not only intralingual (text), but extra lingual (context). Following is the discussion of each data in the humorous comments of the citizens with the theme of the 2019 Presidential Election reported by Kumparan online media.

Not only is the queue-free hospital admission policy, but it is also free of barriers to the heart's entrance (Tidak hanya kebijakan masuk rumah sakit bebas antre, tapi juga bebas hambatan masuk hati si do'i)

In the structure of the first humor comment, there is a language game in the health field which can be described in the phrase "queue-free hospital admission policy" is spelled out as "free of barriers to someone's heart entrance". In this first data text structure there is a description of the ownership of the lingual structure in the language text, namely the ideology of grammatical data. The grammatical data is in the form of ideological words which are fought in accordance with Santoso's opinion [3]. In the first data, the humorous comments of the citizens contained ideological words that were fought for, namely "free of barriers to someone's heart entrance"

In the practice of discourse in the first data there is a process of producing discourse by interpreting the text and context in the data. The phrase "free of barriers to someone's heart entrance" can be interpreted that in the context of romance between men and women there is a struggle to be able to win the hearts of the opposite sex in a way that is difficult enough so that it requires struggle and sincerity to achieve it. The phrase contains humor that can entertain the reader as a text consumer.

In the practice of discourse in the first data there is a process of producing discourse by interpreting the text and context in the data. The phrase "free of barriers to someone's heart entrance" " can be interpreted that in the context of romance between men and women there is a struggle to be able to win the hearts of the opposite sex in a way that is difficult enough so that it requires struggle and sincerity to achieve it. The phrase contains humor that can entertain the reader as a text consumer.

In the stage of explaining (explaining) the sociocultural practices of Indonesian society that women or men who like the target of the opposite sex will find it difficult to fight in order to enter or win the hearts of the target men or women they like. The discourse in this first data is determined by the discourse of Indonesian community institutions, namely in the field of romance. In the field of romance, it cannot be separated from the culture of Indonesian people who pursue or find targets with certain techniques in order to achieve those targets.

When many people are watching TV debates, some people just scroll Twitter timeline waiting for netizen's meme (Saat banyak orang yang nonton debat TV, beberapa orang justru scroll time line Twitter nunggu memenya)

In the structure of this second humorous commentary text, amid the seriousness of the Indonesian people listening to the 2019 presidential election debate, there is a lack of seriousness that is still related to the first part of serious activity, which can be described in the phrase "when many people are watching TV debates," and the less serious part "some people just scroll Twitter timeline waiting for netizen's meme". This is related to the activities of citizens in active social media Twitter. In this first data text structure, there is a description of the ownership of the 
lingual structure in the language text, namely the text structure in the form of transparency in the data, that is, "some people just scroll Twitter timeline waiting for netizen's meme".

In the practice of discourse in the second data there is a process of producing discourse by interpreting the text and context in the data. The clause "When many people are watching TV debates" can be interpreted that in the context of the production of discourse there is an interpretation of the text and the context of citizenship as the Indonesian people who most certainly are enthusiastic about listening to the third round of the presidential election debate. However, in the next clause "some people just scroll Twitter timeline waiting for netizen's meme" can be interpreted that in the heterogeneous context of citizens as Indonesian society there are also groups of citizens who are less enthusiastic about listening to the presidential debate, but more enthusiastic about activities as responders in the context of interactive discourse according to Saifullah's opinion in the previous part of this paper. The phrase contains humor that can entertain the reader as a text consumer.

In the socio-cultural practice of citizens as Indonesian citizens in the group of citizens there are two groups of groups in activities related to the broadcast of the 2019 presidential election debate one group is very enthusiastic about listening to the debate by putting aside social media activities, whereas other groups are very enthusiastic about social media both as consuming responses from responders to interactive discourse on internet media. The two groups cannot be separated from the life of the vast Indonesian community.

\section{Allegations against a cat that is considered apathetic because it was sleeping during the 2019 Presidential Election Debate (Tudingan terhadap seekor kucing yang dianggap apatis karena sedang tidur saat Debat Pilpres 2019 berlangsung)}

In the structure of the third humor comment text there is a convention of interaction, namely control between participants according to [3]. The inter-plasticity control is shown in the apathy of a sleeping cat during the 2019 presidential election debate broadcast. Participants in the context of the 2019 presidential election debate consist of citizens as the presidential election observers and cats as animals who are not concerned about the ongoing debate. This is related to the seriousness of the Indonesian people listening to the 2019 presidential election debates, there was a seriousness by another participant (a cat) who slept.

The purpose of this third humorous comment is that in the midst of the seriousness of the Indonesian people listening to the 2019 presidential election debate, there is a lack of seriousness that is still related to the first part of serious activity, which can be described in the "Allegations against a cat that is considered apathetic because it was sleeping during the 2019 Presidential Election Debate" became a participant who was not serious about responding to the 2019 presidential election debate. This was related to the activities of citizens in active social media Twitter. In this clause there is humor that can entertain the reader as a consuming text.

The assumption that Ma'ruf is speaking as if he is delivering speech in Ramadan activities activities (Anggapan bahwa Ma'ruf saat berbicara seperti saat sedang mengisi kegiatan ramadhan)

In the structure of the fourth humor commentary text there is a metaphor, namely the clause "Ma'ruf is speaking as if he is delivering speech in Ramadan activities". The purpose of this humorous fourth comment is in the midst of the seriousness of the Indonesian people listening to the 2019 presidential election debates, there is a serious lack of discussion leading to humor that still has a relationship with the first serious part of the activity, namely the 2019 presidential election debate. Which can be described in clauses and less serious parts " Ma'ruf is speaking as if he is delivering speech in Ramadan activities". This is related to the activities 
of citizens as Indonesian people who are mostly Muslim following Ramadan activities. In addition, the humorous commentary can be analyzed in the style of Ma'ruf's rhetoric as candidate number 1 (one) presidential candidate pair who can be said to be a religious speaker. This can also be related to the sociocultural practice of Ma'ruf amen as a Kiai who previously served as Chair of the Indonesian Ulema Council (MUI). The clause contained humor in the hearts of citizens about presidential elections that could entertain readers as consumers of texts.

Socio-Cultural Themes: 'Our' culture is to fall in love with someone who can't be had (Tema Sosial Budaya: Budaya 'kita' itu jatuh cinta dengan orang yang tidak bisa dimiliki)

In the structure of the fifth humor comment text there is a vocabulary, namely the clause "'Our' culture is to fall in love with someone who can't be had" In the practice of discourse in the fifth data there is a process of producing discourse by interpreting the text and context in the data. The clause "'Our' culture is " can be interpreted that in the context of love between men and women there is culture to be able to win the hearts of the opposite sex in a way that is difficult enough so it requires struggle and sincerity to achieve it. The clause is indicated by the clause "to fall in love with someone who can't be had" The clause contains humor that can entertain the reader as a consuming text.

The purpose of this humorous fifth comment can be explained that citizens as a broad Indonesian community in terms of love there is a sense of love for people who do not love so there is a culture such as witchcraft as a way to get the target man or woman loved. This is related to the activities of citizens as a broad Indonesian community, most of the young people who are active as perpetrators of love relationships with the opposite sex. This fifth data is a form of humor in the form of the hearts of citizens about the presidential election with the theme of debate in the field of Social Culture.

Highlighting the language translator who was judged to be quack when Sandiaga Uno spoke at a very fast tempo (Menyoroti penerjemah bahasa yang dinilai kuwalahan saat Sandiaga Uno yang temponya sangat cepat)

In the structure of the sixth humor comment text there is a vocabulary, namely the clause "Language translator who was judged to be quack when Sandiaga Uno spoke at a very fast tempo". The vocabulary of "overwhelmed translators" is produced by interactive discourse responders through a Twitter account resulting from the observation process when listening to the 2019 presidential election debate broadcast. This sixth humorous commentary can be interpreted that there is humor in the seriousness of the 2019 election debate process taking place. It is also consumed by citizens with humorous acceptance and can also come up with agreement or opinion that is shared in criticizing the appearance of sign language translators for the homeless people displayed in the lower right corner of the 2019 presidential election debate screen.

That is a phenomenon of linguistic humor amid the seriousness Indonesian society listens to the 2019 presidential election debate, there is a serious lack of seriousness that is still related to the first part of serious activity, which can be described in the clause "Language translator who was judged to be quack when Sandiaga Uno spoke at a very fast tempo". This is related to the activities of citizens in actively listening to the 2019 presidential election debate broadcast which is broadcasted by almost all national television stations in Indonesia.

The theme of employment: Empowering the of slaves-of- love so as not to confuse social media with a dark story and sad songs (Tema ketenagakerjaan: Mensukseskan para budak cinta agar tidak galau di sosial media dengan story gelap beriring lagu sedih) 
In the structure of the seventh humor comment text there is a language game in the field of romance that can be described in the clause "Empowering the of slaves-of- love so as not to confuse social media with a dark story and sad songs", namely the ideology in grammatical data in the form of ideological words that are championed. In the seventh data the citizens' humor comments can be interpreted with the struggle in love. This is related to the field of employment which is the most popular field of citizens as part of the broader Indonesian community. The phrase "slave of love" is a representation of a group of youths who love the opposite sex, but are upset because they are rejected and have an impact on responding to the phenomenon of love by actively social media with a sad status update accompanied by appropriate songs. This is related to the explanation of the sociocultural practices of the citizens of the community who are sad when love is rejected and directly affects the upload in their social media accounts. In this data contained humor in the theme of employment in the 2019 presidential election debate which is associated with love afflicted by sadness because it was rejected by the target man or woman loved.

The purpose of this seventh humorous comment can be explained that citizens as a broad Indonesian community in terms of love there is a sense of love for people who do not love. This is related to the activities of citizens as a broad Indonesian community, most of the young people who are active as perpetrators of love relationships with the opposite sex. This seventh data is a form of humor in the form of the outpouring of citizens resulting from life experiences related to the presidential election with the theme of the debate in the field of labor. Citizens are aware of his role as a young man at one time a role as a slave to the opposite sex he likes.

\section{Hoping that the 2019 Presidential Election Debate will also discuss about "goodbye before lost amid feelings of love" (Berharap Debat Pilpres 2019 juga membahas pamit sebelum hilang saat lagi sayang-sayangnya) \\ In the eighth humor text structure there is a metaphor, which is the phrase "goodbye} before lost amid feelings of love". In the eighth data there is an outpouring of citizens about linguistic units of language produced in the discourse on the 2012 presidential debate. Citizens as discourse producers intend to analogize "goodbye before disappearing" in terms of romance, namely goodbye before disappearing from the person being loved. It can be explained that in the broader Indonesian society there are still many love stories that fail at the beginning of dating. This can be caused by many influential factors, including the presence of a third person, even family approval becomes an important factor in the success of the love relationship being lived.

The eighth point is that in the midst of the seriousness of the Indonesian people listening to the 2019 presidential election debates, there is a serious lack of discussion by adding an element of humor to appear humorous in the hopelessness of the presidential debate which will also discuss goodbye before disappearing when in love. Although the love relationship discussed is part of the theme of Art and Culture, it is certain that there will be no possibility of a discussion at the beginning which will suddenly be abandoned as something that is not related to state affairs but individual personal matters. In this case lies the humor in the eighth data. Thus, it can be said that hope is ridiculous.

Expressing the feeling of longing to someone even though he/she is nobody's is not Indonesian culture (Mengungkapkan perasaan kangen padahal bukan siapa-siapa bukanlah budaya Indonesia) 
In the structure of the ninth humor comment text there is the use of vocabulary, namely in the clause "Expressing the feeling of longing to someone even though he/she is nobody's" with the theme being discussed in the 2019 presidential election debate. This led to the presence of the link between the debate theme and the 2019 presidential election in Twitter accounts reported by the online media Coil.

The interpretation of the ninth data intends to describe a culture of missing someone who is generally directed at someone who has a special relationship with the person who is missed. If not, it will create an impression of humor because it seems like a one-sided love. Expressing feelings of longing for people who have a special relationship is a natural. However, if you do not have a special relationship, the disclosure will seem worthless and will only lower the self-esteem of the person who expressed it.

Citizens as young people in the community consider it less important if they express their homesickness to people who are not lovers. This is a common treatment for young people to stay awake in a romantic relationship between a lover or husband and wife without disturbing the sacred relationship of marriage without giving rise to the terms of the actor (usurper / husband) and pebinor (usurper / wife). This sociocultural practice is a cultural representation of the broad Indonesian community in relation to the special relationship between men and women.

Demands the elimination of the culture of people who ask for a treat at a birthday, even though there is no contribution whatsoever (Menuntut penghapusan budaya orang yang minta traktir di momen ulang tahun, padahal tidak ada kontribusi apapun)

In the last humor comment text structure that was reported by online media Kumpil, there was an outpouring of citizens in the 2019 presidential election still around the theme of Culture. In this data 10 there is a vocabulary in the form of ideology of words being fought for. Representation of the words that are fought for is indicated by the clause "Demands the elimination of the culture of people who ask for a treat at a birthday, even though there is no contribution whatsoever". In this clause there is an ideology of rejecting the general habit of requesting a treat when a citizen has a birthday. This is confirmed by the next clause "even though there is no contribution whatsoever".

In discourse practice can be interpreted that citizens as producers of discourse require the elimination of ordinary friends to be removed from the habit of celebrating birthdays. As a form of affirmation, an explanation was added to the clause "even though there was no contribution whatsoever" to state that ordinary friends for citizens were not very important because they had no effect on their lives. The purpose of this last humorous commentary can be explained by the fact that citizens as Indonesian people want to be treated by certain people so that they are not too burdensome for the respondent's finances. In the midst of the seriousness of the Indonesian people listening to the 2019 presidential election debates, there was a lack of seriousness that led to the cuteness of birthday treat requests for people who were considered less important. This is related to the activities of citizens in active social media Twitter.

\section{CONCLUSION}

The use of language in social media in the form of humorous comments by citizens in online media coverage The coil produced a description of three concepts of the Fairclough Model. First, the text structure of humorous discourse there is the use of vocabulary in the form of ideological words that are fought for, grammatical transparency, control between participants, and metaphors. The practice of discourse is the production and consumption of discourse by citizens as responders to the news that is being discussed hotly. The views of individual citizens 
who are mostly composed of young people are closer to the theme of romance in viewing and responding to the 2019 presidential election debates. Sociocultural practices of the broader Indonesian community are more interested in humor with the theme of love rather than the theme of religion, animals and social media where there is only one data.

\section{REFERENCES}

[1] A. R. Saifullah, Semiotik Dan Kajian Wacana Interaktif. Bandung, 2019.

[2] N. Fairclough, Language and Power. London and New York: Longman, 1989.

[3] A. Santoso, Studi Bahasa Kritis: Menguak Bahasa Membongkar Kuasa. Bandung: Mandar Maju, 2012.

[4] G. and G. Y. Brown, Analisis Wacana (Diindonesiakan oleh I. Soetikno). Jakarta: PT. Gramedia Pustaka Utama, 1996.

[5] N. Fairclough, CDA as a Method in Social Scientific Research in Ruth Wodak and Michael Meyer (ed.) Methods of CDA. London: Sage Publications, 2003.

[6] and E. V. Tischer, Stefan and Michael Meyer, Ruth Wodak, Methods of Text and Discourse Analysis. London: SAGE Publications, 2000.

[7] I. P. Baryadi, Bahasa, Kekuasaan, Dan Kekerasan. Yogyakarta: Universitas Sanata Dharma, 2012.

[8] C. Anthonissen, Interaction Between Visual and Verbal Communication: Changing Patterns in The Printed Media. In Gilbert Weiss and Ruth Wodak (ed.) Critical Discourse Analysis: Theory and Interdisciplinarity. New York: Palgrave McMillan, 2003. 